ARTICLE

Received 9 Jun 2015 | Accepted 29 Jul 2015 | Published 13 Oct 2015

DOl: $10.1057 /$ palcomms.2015.24

\title{
From proclamation to conversation: ethnographic disruptions to theological normativity
}

\author{
Natalie Wigg-Stevenson ${ }^{1}$
}

\begin{abstract}
In recent years, theologians have increasingly used ethnographic research methods to strengthen the connections between their theological constructions and the social practices they seek to impact. The migration of these methods into the theological context has raised important questions about theological normativity. This essay draws on the author's fieldwork in a Southern Baptist congregation in Nashville Tennessee to argue that the ethnographic intervention into traditional methods for producing theological knowledge shifts the mode of speech in which normative theological claims can be made from that of proclamation to an anti-hierarchical practice of conversation. The author proposes that ethnographic theologians can use the ethnographic research question to shape the normative weight of sources in the field and what types of normative claims can be made out of that fieldwork in the theological text. She argues that while such a shift in the understanding of theological normativity and, by extension, of theology itself has the potential to threaten methods seeking to preserve the authority of Christian speech in an increasingly post-Christendom context, that this more humble, collaborative approach is better suited to the interfaith, intercultural contexts of contemporary life, all of which face the reality of the contingency of all truth claims, including religious truth claims. This article is published as part of a thematic collection on radical theologies.
\end{abstract}

\footnotetext{
${ }^{1}$ Emmanuel College, Toronto, ON, Canada
} 


\section{Introduction}

/ / 'all are gonna call me a heretic, but ..." Richard began, a mischievous smile dancing across his lips. A white man in his late sixties, Richard was a member and deacon at First Baptist Church, Nashville, Tennessee (FBC), where I conducted a yearlong ethnographic study in $2010{ }^{1}$ He frequently used such words to preface a statement he suspected other members of our Sunday night, adult education theology class might find controversial. And each time he did, my ears would prick up to attention. Far from excluding his point from our spirited conversation, labeling it as heresy actually seemed to make it easier for the gathered group to hear it. I wanted to understand why that was the case.

FBC had ordained me to ministry the year before I began the fieldwork for my doctorate in Theological Studies there. ${ }^{2}$ Indeed, I chose to do my research at a church where I was not only a member, but even a leader, in part because I was intrigued by the epistemological possibilities inherent to practices of deep belonging. That belonging not only gave me embodied access to participant observation in FBC's adult education programme but actually made me responsible for teaching in it. Taking quite literally Pierre Bourdieu's notion that the ethnographer does not simply observe but actually constructs her object of study, I designed a short series of adult education courses that could both serve the community's interests and provide the data for pursuing my own ethnographic theological research questions (Bourdieu, 2006, Chapter 1). ${ }^{3}$ In particular, I was interested in how one might nurture the practices where "everyday" and academic forms of theological knowledge already overlap, where they already compete and cooperate with each other in order to create fresh possibilities for Christian thought and action. ${ }^{4}$ By teaching historical theology courses on particular doctrines or, as I called them for our non-academic context, "Topics in Theology", ${ }^{5}$ I was able to facilitate conversations that explicitly incorporated the ways class members articulated their everyday experiences of faith with the concepts, debates and movements arising from what academic theologians typically take to be more authoritative, normative Christian traditions.

With my epistemological interests focused on studying how the borders constituting acceptable Christian thought and action might shift and change, statements that any of my research partners made about "heresy", particularly playful statements, grabbed my attention. It is certainly the case that the types of theological claims Richard frequently prefaced so mischievously would more accurately be classified as heterodoxy than outright heresy. Not only did such technical distinctions tend to fall beyond the scope of interest for the congregants who attended the classes I taught, however, but we might also note that the borders separating heresy, heterodoxy and orthodoxy from each other have become increasingly difficult (and decreasingly desirable) for academic theologians to maintain as well. As Kathryn Tanner has persuasively argued, the types of difference that have the potential to generate slippages and changes in what constitutes acceptable Christian belief and practice exist not only beyond but also within the boundaries of recognizable Christian identify (Tanner, 1997, 51). Any so-called other to mainstream Christian norms should no longer be perceived as a threat impinging from outside those norms but, rather, as a possibility erupting from within them.

Of course, the willingness to see lax border control between heresy and orthodoxy as a possibility for, rather than threat against, the life of faith depends much on one's perspective. As I demonstrate in the first section of this essay, our increased awareness regarding the historical and cultural contingency of all truth claims, including all religious or theological truth claims, has garnered a spectrum of academic theological response, particularly $v i s-\grave{a}$-vis the issue of theological normativity: from those accused of naively safeguarding some untainted essence of the Christian Tradition from such contingency to those accused of lapsing into total relativism and, by extension, nihilism. ${ }^{6}$

As was the case with early debates about heresy, of course, most academic theologians' writings only occupy one of these poles fully when they are described by someone else. Yet, as I hope becomes clear through this essay, whenever any of us gets too close to either of the spectrum's ends, prizing either stability or change too highly over the other, then we lose our capacity to speak meaningfully within, from and to the ongoing traditions and practices that shape the life of faith.

Indeed, it is this metaphor of theological speech that will guide the argument of this article. As Tanner (1997) rightly notes, the lax border control already described has the potential to create fresh possibilities for Christian thought and action because it opens space for previously marginalized voices to contribute to the construction of Christian identity (51). It reveals, rather than suppresses-and, most importantly, actually celebrates-the diversity internal to Christian life. In this context, I argue, the theologian should not be heard speaking from outside the racket and clash, whether she does so in an effort to maintain or disrupt the status quo, although my own tendencies lean towards the latter. Rather, the academic theologian's speech should arise from within that exuberant and contested space. She speaks from within that space not only to articulate, but, more importantly, to facilitate and perpetuate the conversation happening therein, and to carry that conversation to a broader audience as well. It is this shift in the dominant metaphor for describing the nature and task of theology-from that of proclamation to conversation-that guides my comments about theological normativity in what follows.

Tapped into the energy of such border skirmishes, the theologian attempts to facilitate the types of negotiations that can bear fruit. In some cases, she seeks to maintain the peace, in others she enacts revolution. It all depends on what she discerns is required in the context. That there is no longer a stable, a priori structure available for the theologian to use that can automatically authorize the normative status of her theological sources and claims does not mean that all her claims become relative, however. Rather, in light of this absence, the academic theologian becomes responsible for discerning, articulating and even arguing for the particular way in which her theological construction is shaped by and productive of normative claims in each and every project she pursues. By making this claim, I also intend to imply another: that, while concerns about normativity have been most frequently levied at theological methods making the so-called turn to culture or turn to practice (and, in particular, at those that have deployed ethnographic methods in their theological research somehow), even the most textual and traditional of theological approaches can no longer presume the normative status of their own sources and claims. The challenge that continues to face all academic theology in light of the historical and cultural contingency of all truth claims is not how we can preserve an essence to Christianity that protects normativity in the face of such contingency. Rather, the challenge-and the gift-relates to how we might remain theologically faithful given our acknowledgment that there is no normative essence to Christianity (either inherent to it, or gifted from without). Or, at least, there is no normative essence that we can grasp and hold on to with any sense of permanence, or any sense of trust will that it truly has been or will continue to be gifted with enduring discernibility.

While all theologians face this challenge, ethnographic theologians in particular have some fruitful insights to share regarding how we might respond to it. My proposed response, outlined below, uses a theologically revised understanding of the ethnographic research question to carry the practices of theological normativity 
at play in the fieldwork context over into the writing of the theological text. I return to the example of heretical speech from my own fieldwork to explain the context-specific normativity that structured our shared practice of theological conversation at FBC and how that context specific theological normativity structured the text I subsequently wrote. I conclude the essay with some insights about how this theological use of ethnography shifts the normative function of academic theology, and why this might be of interest to other non-theological disciplines engaged with qualitative methods.

\section{Ethnography as dogmatics versus ethnography as theology}

By now, most academic theologians agree that theology is always culturally located. The capacity for concepts such as reason, tradition and experience, for example, or revelation or the self to secure a firm foundation for theology, has crumbled under critiques extending throughout modernity. Consequently, theological construction faces a situation that Sheila Greeve Davaney has aptly described as echoing "all other human cultural creations". As she puts it, "religious interpretations of reality are contingent, tied to place and time, funded by the past and reflective of and contributors to present material and social relations" (Greeve Davaney, 2000: 148). Even our most sacred traditions do not stand outside of culture but, rather, are constituted by-as they also constitute-the wide array of social practices that make up our everyday lives. This means that not only are the kinds of normative claims a theologian might make always in a state of flux, but so too are the normative sources that contribute to how we make those claims.

Theologians have responded to this destabilizing of theological authority in a variety of ways. Some, somewhat counterintuitively, have accepted that the resultant situation is a relativism for all claims, and have gone on to reassert the superiority of Christian theological claims within this new marketplace of ideas. To make such a move, however, requires that they posit a stable (that is, not contingent) repository for God's ongoing self-disclosure: the church, for example, or an authoritative rendering of the Christian traditions. A major problem with such approaches-well rehearsed across a number of different academic theological camps, by now-is that to keep this repository stable requires idealizing it (Williams, 1992; Smith, 2004; Scharen, 2005). If the church is the location where God's kingdom is made visible or where the Trinity is embodied, or if the Christian tradition is the thread through which a non-violent counter-narrative for creation is told, then church folk really should not look and act as much like other folk as it seems they do. Bracketing off the daily squabbles of church life causes a significant enough distortion of our ecclesial descriptions. Bracketing off the violence that, far from being an aberration to our Christian traditions, has actually contributed to constituting them, distorts them beyond recognition. For example, theologians cannot ignore, but instead must deeply engage, the theological ramifications of clergy sexual-abuse scandals. Our theologies of reconciliation should be shaped by repentance of explicit Christian complicity in various forms of cultural imperialism, or of the persecution of, as well as cultural and literal genocide of, religious, ethnic and sexual minorities in more contexts than can be adequately named in this space.

The problem of idealization is not simply due to the absence of adequate descriptions of Christian practice, however. It therefore cannot be easily solved by the introduction of ethnographic research methods to theological inquiry. Rather, the problem relates to the particular way of configuring the relationship between typically normative theological sources and the theological descriptions of practice. Dogma and description are pitted against each other in a competition, with dogma's victory decided before the match even begins. But when we allow pre-established dogmatic criteria to trump the descriptions of practice that do not quite fit our idealized vision, then those descriptions are, at best, reduced to the status of (distorted) illustrations of that dogma. As such, they contribute little to nothing to the theological construction at hand. Ethnographic theology therefore needs to challenge and reshape traditional theological normativity rather than endeavor to reproduce it, as the following example demonstrates well.

In an influential article written 15 years ago, Adams and Elliot (2000) argued that "ethnography is dogmatics". To make their claim, the authors removed the intermediary step of "ethics" from their combination of Michel Foucault's understanding that ethnography is ethics with Karl Barth's dictum, "ethics is dogmatics" (Adams and Elliot, 2000: 339). Their method proposed that theological descriptions of concrete situations have the capacity to place a moral call on human lives by revealing to us the work of God among us, with which we might partner. They write:

We are describing things, although not naively, as they appear to two Christians who are trying to make God's story our story, and who do not wish to have one mode of speech for describing the world, and a different mode of speech for speaking of God. We are trying to describe God's world ... (Adams and Elliot, 2000: 347)

Adams and Elliot's call for theologians to use the same modes of speech to describe what happens in the world and what God does in the world is laudable. Unfortunately, it results in the latter unnecessarily absorbing the former. Important distinctions between the two thus disappear, as only those details that can be made to fit God's story are narrated. In the Procrustean bed of Adams and Elliot's theological method, richly detailed descriptions from their fieldwork in Northern India are made to serve simply as illustrations-or "parables", as they put it-for how they already understand God to be at work in the world. The fieldwork reveals groups of oppressed people who are able to defeat their more powerful oppressors through various creative means. But rather than going on to tell the longer story of the status quo's return, and the return to oppression for the indigenous groups, Adams and Elliot (2000) proclaim the particular moments of victory as "miracles ... unexpected events that Christians nonetheless expect" (358). The eschatological dogma that shapes their argument requires that the rest of the story go untold.

There are a number of strengths with Adams and Elliot's argument. First, whereas so much ethnographic theology focuses its attention quite narrowly on church life or through the doctrine of ecclesiology, Adams and Elliot expand the ethnographic view to focus on non-Christian subjects in non-ecclesial settings. As they rightly state, "there is no guarantee that what we think of as the Church is really the Church" (Adams and Elliot, 2000: 360). Their research thus strives for a more public, political type of theology that is still rare among the more ecclesiologically focused projects of much ethnographic theological work. Furthermore, by describing concrete practices in significant socio-political detail, naming global dynamics of power, privilege and resistance among various players, Adams and Elliot offer the beginnings of a corrective to idealized theological turns to culture. There is real brokenness in the world, and Adams and Elliot tell stories that have the potential to illustrate this. Unfortunately, their method leads them to gloss over that brokenness before the reader has much of a chance to register it.

In defense of the fact that their stories illustrate only wins, not losses, by society's disenfranchised (and according to their 
theological frame, by extension, God), Adams and Elliot (2000) admit that they "do not yet have a strong enough hold on this idea [i.e., ethnography as dogmatics] to show how it might work out in situations of radical failure" (360). But it is precisely the difficulty of the method to work in situations of failure that must make us question whether it is working at all. Had their ethnography focused on any one of the stories from their context in which the powerless were not vindicated, would we be forced to say that God was on the side of the oppressor, or that God, Godself, was powerless? Either option seems not only untenable to the authors, but also to have been logically excluded from possibility by the pre-established dogmatic criteria that frames the descriptions as illustrations supporting-rather than potentially disrupting or reconfiguring-a particular, already established as normative theological claim.

For a robust approach to producing (rather than presupposing) theological normativity in light of the cultural contingency of all truth claims (including dogmatic truth claims), the alternative to allowing doctrine to trump practice is not, however, to allow practice to trump doctrine. New trends in ethnographic theology seek a more complex arrangement of doctrine and practice than such strictly competitive, hierarchical visions allow. Webster (2012) is right when he claims that "resistance to idealism commonly underlies appeals for the deployment of the social sciences in ecclesiology" (201). But he is wrong when he presumes that those of us making such appeals hold the conviction that "the real is the social-historical" at the expense of the doctrinal (Webster, 2012: 202). Ward (2012) even goes so far in his defense for the theological use of social scientific methods to name the fact that he chooses intentionally to "avoid the word 'real' here [in descriptions of ecclesial communities] because using it valorizes the social over the transcendent, the cultural over the spiritual" (4).

Instead, more recent work in ethnographic theology understands diverse modes of theology-doctrine, practice, dogmatics, everyday and academic forms of theological knowledge, and so on-to be related to each other in non-hierarchical, even conversational, ways, as I am arguing here. These conversations might include moments of competition, but they also include cooperation. Moreover, when doctrine and practice do go headto-head in these conversations, the winner is not pre-determined. Rather, the ethnographic theologian, whose inquiry must be shaped by careful practices of self-reflexivity, discerns an apparatus to negotiate the normative weight of each. Her discernment is guided both by how these different modes of theology relate to each other in the context of her fieldwork and by how she intends to articulate them in the text she writes out of that fieldwork. It should be noted that this process of discernment is not all that different from how theologians traditionally do their work. The writer of a theological text always has the power to discern the structure of normativity for arranging the sources for her argument. The goal with the ethnographic theological process is to include non-textual voices in the process of discernment, and to make the process more transparent. In so doing, theology in these models is thus reframed us a much more imaginative, expansive practice than the narrow focus on dogmatics alone allows. Ethnography, used as a research method for this more expansive view of theology, is thus able to do more work than its attachment to the narrower category of dogmatics allows it to do.

A number of theologians using ethnographic research methods have, in fact, cited Kathryn Tanner's more expansive way of framing the nature and tasks of theology as integral to their own theological constructions (Healy, 2000; McClintock Fulkerson, 2007; Bretherton, 2012; Wigg-Stevenson, 2014). As Tanner argues, theology is, itself, a historically contingent, cultural practice, composed of multiple forms of discourse all competing and cooperating with each other in dynamic ways to preserve, reconstruct, submit to and resist old and new possibilities for Christian thought and action. These discursive forms span a continuum that ranges from ad hoc, context-specific, everyday reflections on the concrete life of faith (what Tanner calls "everyday theologies") to the "specialized theological investigation ... that arises in an 'organic' way out of Christian practice" (what she calls "academic theologies") (Tanner, 1997: 71). All theological creativity is thus shaped by an ongoing interplay of action and reflection, practice and theory, as it "works with an always potentially disordered heap of already existing materials, pulling them apart and putting them back together again, tinkering with their shapes, twisting them this way and that" (Tanner, 1997: 166). Tanner thus maps a much more dynamic theological terrain in which normative sources are deployed and normative claims are made than a practice-doctrine conflation or standoff can make visible.

Following on Tanner's understanding of the nature and tasks of theology as a dynamic cultural practice, new approaches to ethnographic theology insist that a set of Christian practices can have "embedded and embodied within its life substantive contributions to theology and ethics" (Scharen and Vigen, 2011: xxii). As Scharen and Vigen (2011) argue, "rather that pairing ethnographic facts to universal theological truth", new approaches to ethnographic theology apprentice the ethnographic theologian within her field of study so that she becomes able to articulate "those embedded theological convictions as primary theology itself" (xxiii). Historical, doctrinal, textual and traditionally normative theologies are not dismissed from this reflexive process. But they also "do not automatically have privilege over the local theological understandings operative in the lives of those studied" (Scharen and Vigen, 2011: xxiii). In other words, following on Tanner's framing of theology as a cultural practice, new approaches to ethnographic theology fill out the reflexive moment of theological creativity, when the academic theologian begins to assemble that disordered heap of already existing materials scattered on the floor around her. This is when the theologian's apprenticed theological knowledge really starts to matter, because it is her apprenticeship that inculcates her with the instinctual wisdom or, we might say, bodily wisdom required for knowing how to assemble the pieces.

Reflecting on the apprenticeship he undertook in a Chicago boxing gym as part of his own sociological ethnographic project, Loïc Wacquant has some insights that can help us better understand what Scharen and Vigen have in mind here. As he points out, "membership in a category or collective does not by itself make one a good anthropologist of it" (Wacquant, 2005: 457). It is certainly true that my membership at FBC could cloud my interpretations of our community practices as much as it could illumine them. Instead, ethnographic inquiry into any particular social world must be animated, Wacquant (2005) argues, by a "theoretical problematic" (458). The knowledge produced by the fieldwork, as well as the norms that shape that knowledge, are all configured by the particular research question that is brought to the context. Drawing heavily on Wacquant's (2005) theory in my own fieldwork, my theoretical problematic mirrored his: to borrow his words, I wanted to "take full epistemic advantage of the visceral nature of social life", not to do theology "of the body (as intelligible social product)", but rather to do theology "from the body (as intelligent social spring and vector of [theological] knowledge)" (46). ${ }^{7}$ As an ethnographic theologian, however, I required more than a theoretical problematic to animate my inquiry. My research question needed to be comprised of a theoretical-theological problematic. As already noted, in terms of a theological research question, I wanted to 
explore the relationship that Tanner had mapped between everyday and academic theologies. I wanted to find and nurture the places where these discourses already overlapped for the purposes of collaboratively creating fresh possibilities for Christian thought and action.

With ethnographic research, the research question produces knowledge by using methods discerned as appropriate to both. So, as I began to plot out my research methodology in light of these problematics, I saw a convergence between them in light of the type of theological knowledge I was trying to produce. My own bodily knowledge was one of those locations where everyday and academic theology converged. Because of the organic overlap of these forms of theological discourse, as Tanner describes them, the same would be true of most any academic theologian, whether her fieldwork is conducted in a community to which she belongs or not. Nevertheless, to an even greater degree, as a member and leader at $\mathrm{FBC}$, and as an academic theologian, I was apprenticed both in the everyday theologies of the community I was studying and in the academic theologies of the Christian traditions. Through my own particular configuration of theological agency, I therefore embodied the skills required for nurturing that place of overlap. And this is how the particular methodology of the Sunday night classes I taught began to be formed-precisely out of the ways I had been theologically apprenticed.

\section{Theological normativity: from the field to the text}

I have been suggesting that the image of the academic theologian as someone who proclaims theological truths to an eager audience is increasingly outdated, whether or not that theologian uses ethnographic methods as her primary research tool. Rather, when we understand theology itself to be a cultural practice, the image of conversation-both within the research process and within the textual productions arising from that research-is much more suitable. The ethnographic theologian in this model thus shapes and facilitates particular theological conversations within her fieldwork (drawing on her academic theological knowledge to do so), and then shares the wisdom from those conversations with her academic communities (drawing on her everyday theological knowledge to do so). Theological normativity in the latter conversation is shaped by its mode of functioning in the former conversation.

For this reason, in this section I initially outline how my research question/methodology positioned traditional theological norms in my fieldwork conversations as dynamic strategies for producing discourse, rather than as rules for limiting discourse. Normative sources functioned similarly in the theological text I wrote out of my fieldwork-also conversationally-to help produce theological claims whose normative weight was shaped by the research question used to produce it. This model offers a less hierarchical, more collaborative understanding of the practice of theology than the dogmatic models outlined above allow. As a result, it is better suited to the post-Christendom context in which we live-where theology is no longer the "queen of the sciences"; where Christians are increasingly aware and rightly repentant of the damage our faith has done in the world; and where, as a result of both these facts, theological humility is a much more appropriate virtue than theological bravado. If we are to seek to share the wisdom of our traditions with each other and with a broader culture, we must learn to do so gently, co-operatively and in mutual partnership with others.

Lest I idealize our understanding of "conversation", however, let us recall my fieldwork context that grounds my use of this metaphor. The adult education theology classes I taught at the church on Sunday nights functioned like laboratories for theological experimentation, as I introduced ideas from Christian theological traditions to the class members for discussion and debate. We all brought different gifts to the table as we drew on our life experiences, cultural competencies, common sense, faith perspectives and more. The traditionally authoritative Christian traditions that I taught were not treated as trump cards, predetermined as always already able to defeat any ways in which the gathered people's faith differed from some set of pre-established rules. Neither did our life experiences automatically trump the wisdom from the Christian traditions, as if what was true for me was all that mattered. Rather, different kinds of theological norms and claims interacted with each other throughout our conversations in different ways. Indeed, we argued and wrestled with the traditional figures, allowing them to re-shape some of our beliefs and practices and we rejected, reconfigured and reimagined some of their views. We also argued with each other, experiencing occasional frustration with each other, a frequent difficulty at engaging more contentious issues (particularly those related to racism and sexuality), and producing numerous moments when our practice felt short of the ideals of community. While our conversations overall were friendly, eager and enjoyable, they also were at times fraught. Church life is complex that way.

A thread of conversation that surfaced across a couple of evenings for our group will help illumine the dynamics of our conversation. On the night when our topic was, "Reformation Theologies-Where is God and What is He Like?" I framed our conversation about Martin Luther around the heresy of patripassianism. ${ }^{8}$ I intended to pick this concept back up with we got to our studies of Jürgen Moltmann in our class titled, "20th Century Theology-Why Does an All-Powerful God Permit an Unjust World?" so I was weaving themes that I projected to be a part of that upcoming class into our discussion as well. I had shared some reflection questions with class members ahead of our meeting to frame the conversation ("If God is three in one, and Jesus suffers on the cross, does that mean the Father and the Holy Spirit suffer too?", "What would be the problem with that?" and "What would the nature of their suffering be?"). After opening the class with prayer, we began discussing these questions, which some of the class members had taken the time to engage on their own ahead of our time together.

The opinions held by class members were diverse: some wanted to say that the Father and the Spirit do not suffer alongside the Son. This was an evening when Richard deployed his own playful modes of heretical speech by trying to undo my Trinitarian framing altogether, admitting that he only really used traditional Trinitarian names for God "to prevent being condemned as a heretic", but that really, "the older I get, it's an elusive thing". Others wanted to claim that the whole Trinity suffers with the Son, and to connect this suffering with God's compassion for all human suffering, including their own personal suffering. Other class members wanted to distinguish between different kinds of suffering-those that were appropriate to attribute to God and those that were not. Throughout the conversation, whenever it seemed appropriate, I would define relevant philosophical and theological concepts. For example, I spent some time on Divine impassibility, and unpacked how this philosophical concept had shaped a particular understanding of God in the Christian traditions. And this helped us to question what foundational concepts might contribute to our own definitions of God without our conscious awareness of them.

As the teacher, I used traditionally authoritative Christian traditions to help class members bolster, challenge, reaffirm, reformulate and reimagine their own views. At some point in the conversation, intuiting that the name Martin Luther would likely hold more normative weight for the class members than philosophical concepts from ancient Greece could do, I offered a mini-lecture on how Luther had opened the space in our 
traditions for concepts of Divine suffering to squeak through and, in anticipation of the class we would have in a few weeks, I briefly connected this aspect of Luther's theology with twentieth-century approaches to theodicy. Throughout the conversation, there were no definitively "right" or "wrong" answers, just the continual gentle nudging into varying degrees of reconfigured thought that can come from spirited conversation across difference. Different concepts would hold different weight, but that weight seemed generally to be negotiated by the conversation itself rather than pre-determined. I do not think that anyone "changed their mind" in any major way about what they believed. But they did unpack their beliefs, come to understand them more deeply, hold them in fresh ways, and integrate them more fully with their other beliefs and practices. ${ }^{9}$

Moreover, in the midst of all this debate and discussion the group demonstrated a somewhat surprising willingness to engage with a concept-patripassianism - that I had told them outright was a heresy. Some simply rejected its heretical status, clearly convinced-to varying degrees of conscious awareness-by twentieth century theological movements that had also embraced an image of a suffering God. These newer theologies, as well as the class members' own experiences of God's presence in their own suffering, thus held greater normative weight in their view than the more authoritative Christian traditions, making the status of heresy moot for them. Others wanted to flirt with the orthodoxy/heresy border, developing their own everyday theologies in a way that played with and straddled both sides of it. And yet others wanted to make sure they positioned themselves firmly on the "right" side of the divide, guarding their own constructions from heretical danger. As one class member put it, she felt comfortable playing with all kinds of theological concepts except those related to God's own being: "I think that's what makes the Trinity such a kind of scary concept to wrestle with. You don't wanna get it wrong ... You remember that vengeful God!" However each person embraced, feared, scoffed at, played with or rejected the "heresy", though no one seemed to position anyone else as outside our fold based on their theological choice. Heresy provided fodder for constructive theological debate, to be kept inside the borders of our conversation rather than expelled like a scapegoat to somewhere beyond them.

Far from imposing a rule for belief on the gathered community, then, my act of introducing an authoritative Christian theological norm to our debates, of even naming a so-called heretical limit, functioned in a more creative, productive way. Bourdieu (2006) has argued that ethnographers commit a type of intellectual or even epistemological error when they construe the norms they discern to be patterning human behaviour within a community of practice as rules (1-30). There are, of course, norms at work in communities, and they are often implicit, unconscious and, as such, unarticulated: embodied in members' own unconscious theological agency-their habitus, as Bourdieu (2006) describes it (78-87). These norms are, in fact, shaped by the types of theological apprenticeship each person in the room has cultivated through their ongoing participation in Christian social practices. At certain moments, particularly when the tacit performance of those norms ceases to function as fluidly as they usually do, Bourdieu argues, they might surface to articulation by the agents who embody them. Thus articulated, the norms can be consciously engaged, rejected or reaffirmed. ${ }^{10}$ In this way, norms that contribute to shaping a community's life (and which, by extension, the community's life contributes to shaping) function less as rules for limiting action and more as strategies for enacting action-or, as other theorists have put finer points on it, strategies and tactics for enacting submission and resistance to the status quo of a community's practice (de Certeau, 1988: 34ff.; Ortner, 1996: 17). ${ }^{11}$ Ann Swidler has even described these patterns as assembling something of a tool kit that is available for use by agents, particularly in moments when things feel unsettled. When old ways of thinking and acting no longer seem to be working, agents can take tools out of this tool kit, and can use them to fashion new modes of thought and action-not unlike the act of bricolage that Tanner uses to describe theological creativity that I outlined above (Swidler, 1996).

I was certainly interested in what my research partners had to say about the Trinity, about the suffering of God, about the cross and other such theological topics. At the very least, I was curious to know what my co-congregants believed because these were the people with whom I practiced so much of my life of faith. But the particular beliefs themselves were not the topic of my research. If they were, I could have just asked people what they believed, or tried to discern their beliefs in action. My research interest in the relationship between everyday and academic theologies required different methods. I had to bring my academic apprenticeship into our conversations-not just ask questions, but actually incorporate academic knowledge into the conversations we had, and then track and respond to and reconfigure my own plans in light of what the gathered people did with that knowledge. Had they refused to engage concepts of God's suffering, their acceptance of the heretical limit would have nudged my own use of academic theological knowledge in a different direction. Their flexibility and willingness to play with theological knowledge, however, opened space for me to become more adventurous with what I introduced to them. And so my research question guided a process that was less about a final theological product or definitive claim we would agree, as a group, could be made about God, and more about the process itself. Theology became, as Tanner (1997) puts it, a "hybrid relational affair", such that engagement was valued over agreement (57). By extension, the ethnographic theological text needed to convey that engagement, rather than codify any moment of agreement arbitrarily removed from the larger story.

The research question shaped how theological norms functioned within the fieldwork component of my ethnographic theological research, but it also shapes how they function in the writing of the academic theological text. How do the claims produced by the conversation that I had with my research partners on various Sunday nights have any authoritative, normative weight for a different, potentially wider, academic theological conversation? Why should anyone care what a selfselected, non-representative, contingent group of Baptists said in response to a series of prompts in a church basement in 2010? The answer, according to my own research question, is that the significance of the project does not lie in what any individual class member said, so much as how they said it or, rather, the process by which they came to say it. My particular research question and methodology was not intended to treat the group's everyday theologies as sites of divine revelation, now to be transmitted as authoritative over and against the theological traditions they both embodied and rejected. Rather, my particular research question and methodology limits the kinds of normative claims I can make to the kinds of claims that precise method can produce. Rather than drawing on some $a$ priori structure of authority for what can make a theological claim normative, I used the research question to shape an agenda-a limiting, but therein also productive agenda-for how any claims I made out of my research would have any import for theological conversations in the academy.

Our ecclesial theological conversations allowed me to test how dually apprenticed knowledge from the everyday and academic forms of theological knowledge may or may not be able to contribute to stimulating processes of theological stagnation and change, for example. I could make concrete claims about how bodies and bodily differences produce and bear everyday 
theologies. I could explore what, in a particular theological construction, makes it more or less difficult to theorize in a more disembodied mode. I could explore the interpersonal dynamics, particularly those related to power and privilege, of theological construction. And, in fact, I was able to test how authoritative theological norms function in everyday Christian practice. Rather than collapsing everyday and academic theologies into each other, I sought to stretch out the space between them to see what could be created out of that space. In this way, I sought to tell theological stories that avoided being, in Jordan's (2013) words, "violently simple or demonically final" - which is, in my view, the real gift that ethnographic theology brings to conversations about normativity (5).

\section{Extending the conversation}

Of course, not every theologian wants to shape their research around questions related to the nature and tasks of theology as I have done here. So we must ask if a model that uses the theologian's research question to shape theological normativity in both the research and writing process could be used for projects that are not related to theological methods. Does this model reject the possibility of making more traditionally dogmatic claims? Or can we imagine ethnographic frameworks that could produce dogmatic, rather than just methodological or more broadly theological claims? My answer to this question is both a resounding "no" and an exuberant, "but still, yes!" No, because the contingency of all knowledge means that we can no longer make an unqualified statement about any aspect of social reality, let alone about divine reality. But still, yes, because the research question provides us with a framework for making the types of qualifications required for humbly hoping that what we discover about God in our research might be true. But still, yes, because we need a structure for our hope that something of the Divine is revealed in both our Christian traditions and our contemporary practices of faith or, more to the point, that something of the Divine is revealed by the dynamic interplay between the two. In closing I offer a few insights into what kinds of normative dogmatic claims might be able to be produced by this model, the role they might play in a broader theological conversation and the ways they might contribute to a broader still crossdisciplinary ethnographic conversation.

As this essay has made clear, the intervention of ethnography into the production of theological knowledge helps us to limit the scope of theological inquiry by using a research question that incorporates the theoretical and theological dimensions animating the inquiry. As already noted, such limits are always present in any theological project; they just are not always named. By using the research question to clearly articulate these limits, then, we halt theological normativity from presuming any false objectivity or from making misguided claims to universal import. But there are other ways we could consider for articulating this limiting framework. For example Ted A. Smith suggests that ethnographic theologians take the risk of making dogmatic claims, and offers an adaptation of the model he uses to frame his own histories of practice as a project of ethics to do so. Smith's (2013) work draws on an argument by Theodor Adorno, whose critique of positivism led him to claim that "some kind of metaphysics" was crucially necessary for any justice-oriented philosophy, but only inasmuch it could actually engage (rather than ignore) "its own entanglement in social relations" (7). "Only when the [metaphysical] concept is confronted with some concrete social entity", Smith (2013) argues, "does it cease to be identical to itself and begin to realize its truth content" (7).

In the confrontation between a sociological description and the normative dogmatic claim that interprets it, then, the ethnographic theologian stretches out a kind of "charged space" in which she can actually begin to "do the work of hope", rather than simply proclaim that work done (Smith, 2013: 7). To illustrate his model, Smith (2013) offers the example of an ethnographic theologian who, facing a context of congregational growth, risks making the more universal claim, "God did it," while simultaneously insisting on that claim's fallibility (7-8). In other words, facing a social situation that has verifiable social causes, the ethnographic theologian might still make a dogmatic claim about how God works in the world, about how Divine and human agency labour together, and about the very nature of God based on what she discerns God as deciding to do among a particular people. What would make such an argument "interesting", Smith (2013) notes or, we might say, what makes it even work at all "would not be the ways that the concept fit the entity, but the gaps between the two-the ways that the social phenomenon outran, fell short of, exceeded, swerved around, and otherwise failed to realize the theological concept" (7). Dogmatic claims would not directly interpret ethnographic descriptions, therefore, just as ethnographic descriptions would not merely illustrate dogmatic claims. Rather, in the ethnographic theologian's willingness to claim that the dogmatic and the descriptive each comprises the realm of the real, she allows the two to create together a dialectical friction in their mutual conversation, which in turn generates an unpredictable overflow, an ungraspable transcendence that we can hope can reveal something true about God's presence in the daily flow of life.

As with the model I have proposed in this article, Smith's (2013) model insists that any normative theological claim derived from the ethnographic context must come carefully packaged such that the particular nature and justification of the claim are clear, as is the extent of its authority and the method by which it has been made (4-5). These are all the types of questions I have endeavored to shape in this essay using a research question, but as other ethnographic theologians have demonstrated, they can be shaped in other ways as well. For example, Ward (2015) answers them by interpreting theological knowledge as a form of spiritual "abiding" that recognizes the "perilous faithfulness" of normative theological claims. Alternatively, McClintock Fulkerson (2007) uses the metaphor of a "wound" that requires healing to describe in theological terms the space between a community's intention and actualization of racial reconciliation. And Kaufman (2015) uses the ethnographic value of reflexivity to make naïve understandings of implicit theological normativity explicit. Each in their own way creates the kind of generative framework necessary to qualify normative dogmatic and theological claims without denying their possibility. I propose that the ethnographic research question offers a helpful tool for this task, but the field of ethnographic theology offers multiple options. Which framework for securing normativity anyone chooses matters less than the fact that they choose-or, rather, construct-one, rather than relying on an idealized vision of the church, for example, or an overly authoritative framing of a nonetheless contingent Christian tradition.

Second, the normative weight that the types of limited claims I have outlined in this essay can have in broader theological contexts will, in large part, be shaped by the ways in which they are picked up (or not picked up!) by those already-ongoing theological conversations. Ethnographic theology, as an emerging field, will likely need to continue to defend itself against the accusation that it is unable to produce more universally reaching normative claims. Ethnographers working with qualitative methods across the disciplines have long been defending themselves against similar charges. In addition to the defense for such claims that I have already articulated, I also want to draw on insights from the types of ethnography that might reveal some 
alternative goods-unhinged entirely from the desire for universality - that ethnographic theology can offer to the broader field. As social scientist Bent Flyvbjerg has convincingly argued, the fact that descriptive approaches to ethnographic study do not produce universal claims is, in fact, their strength, not their weakness. It means that the knowledge these practices of research do produce functions in a more pedagogical, more formative way. They are the forms of knowledge that contribute to our ongoing apprenticeship within certain fields of practice. If one of theology's tasks is to shape the life of faith, then we need to make our normative claims in ways that can be integrated into that process. As Flyvbjerg (2001) argues, drawing on the Dreyfus model for human learning, stories provide the types of wisdom required to move us from being novices to experts within a field of practice (Chapter 2). By letting go of the drive towards false universality, ethnographic theological descriptions have the potential to help us pursue a crucial theological task that has long been overlooked and underrepresented in mainstream theology. By having only a little to say, those claims that contribute to the ongoing, humble collaborations by which communities share their traditions with each other might, in the end, have the most to say.

Finally, because the arguments I have made here accept the contingency of all theological sources and claims, they have also made theological knowledge accountable to a wider body of knowledge than it has typically privileged for the adjudication of its normative viability. In this way, the model for theological normativity I have outlined here intentionally opens theology up for constant revision, by voices both internal and external to its core. This model is therefore constructed in an intentionally interdisciplinary way. Moreover, the fact that this argument is theologically distinctive, but without using that distinction to presume special exemption from contingency, also opens it up for critical dialogue with other disciplines that use ethnographic methods. Because of the very nature of theology as a complex cultural practice, theological ethnography provides fields of study that have a uniquely organic connection to the modes of inquiry into them. At the same time, my argument here has touched on debates crucial to qualitative methods: for example, the researcher's insider/outsider status, the epistemological problems and possibilities of apprenticeship and/or belonging within the field of study, power relations between the researcher and her research partners, and more. Further exploration of these crucial debates within a theological framework has the potential to produce fresh insights for non-theological uses of ethnography as well. Beyond the content of our ethnographic theological projects, the ethnographic methods we develop to pursue interests that are native to our own discipline can provide interesting alternatives for non-theological approaches to engage in spirited conversation as well.

In sum, my goal here has been to articulate an approach for making normative claims in theological methods, particularly ethnographic theological methods, that is appropriate to the context in which we now to our work. Thoroughly contingent, no longer "queen of the sciences", with penitent awareness of the ways sin and violence have contributed to shaping our traditions, and operating in increasingly post-Christian, post-Christendom societies, theology can no longer imagine itself as able to boldly proclaim truth from outside the exuberant chaos of daily life. Rather, theology must take the risk of stepping inside the actionor rather, the risk of acknowledging that is where we have always been - to humbly extend the hand of friendship to those we meet therein. It must seek to work with faithful partners beyond those voices codified in authoritative texts, and whose lives still bear the presence of God. Theological normativity in such a model shifts the goal away from proclamation, which requires hearers of the word, towards conversation. This conversation, we hope, has the potential to inspire the kinds of faith formation that cultivates doers of the word instead (James, 2001, 1:22).

\section{Notes}

1 FBC is composed of primarily White, primarily middle to upper middle class members. It is located in the downtown core of Nashville. Approximately 700 people attend services on a Sunday morning.

$2 \mathrm{FBC}$ is one of the few congregations in the Southern Baptist Convention willing to ordain women to ministry. This decision is in line with the congregationalism of Baptist polity, which allows individual congregations to follow their own conscience on this matter.

3 I received IRB approval for these methods and received informed consent from all study participants. People who attended the classes I taught knew that I was conducting research for my doctoral dissertation, and that I would use information from our sessions in subsequent academic publications as well. They knew that I digitally recorded all of our classed and transcribed the notes, that their identities and identifying characteristics were protected in this process and would be anonymized in any written publications. Our classes functioned a bit like group interviews, or participatory action research methods, as we generated conversation among ourselves that was oriented towards better understanding, and perhaps changing, our own theological beliefs and practices.

4 I adopted this theological framework from Tanner (1997) and will unpack it further later in the essay.

5 The first course was called "Topics in Theology: Jesus Christ and Salvation" and the second, "Topics in Theology: God as Trinity". Across both courses we engaged the theologies of the Gospels, Justin Martyr, Origen, Arius and Athanasius, Augustine, Gregory of Nyssa, Anselm, Abelard, Aquinas, Beatrice of Nazareth, Marguerite Porete, Luther, Calvin, Descartes, Pascal, Kierkegaard, Kant, Schleiermacher, Hegel, Karl Barth, Karl Rahner, Gustavo Gutierrez, James Cone, Rosemary Radford Ruether, and Elizabeth Johnson.

6 John Milbank tends to have the former accusation levied at him and, while his work does endeavor to preserve the authority of the Christian tradition, his argument is far from naïve. At the same time, Milbank levies the latter accusation against theologians who use social scientific methods, also an unfair claim (see Milbank, 1990).

7 Wacquant's original quotation, of course, outlines his desire to do sociology (that is, not theology) from not of the body.

8 While I tend not to use masculine language for naming God in my own personal prayer, or when I name God in academic settings, I did tend to use it while teaching theology classes in my Baptist church. This, of course, marks one of those places of compromise, of conformity to a particular setting, that we all make in order to maintain our sense of "belonging". I rarely used feminine language for naming God in this context as doing so would have been unintelligible to most church members.

9 For a fuller discussion of the kinds of impact these conversations had on various class members' own theological beliefs and practices, see Wigg-Stevenson (2014: 101-115).

10 See discussion of "doxa, orthodoxy, heterodoxy" in Bourdieu (2006: 159ff.).

11 Sherry Ortner suggests that anthropologists focus too much attention on modes of cultural reproduction, and fail to attend to the slippages that occur and, thus, bring about cultural change. She recommends paying attention to those moments of slippage as moments of resistance to the status quo. In an expansion of Bourdieu's understanding, Michel de Certeau distinguishes between the strategies available to those who have the power to explicitly shape a field of practice at the structural level and the tactics from the underside that are deployed by those who do not have such power.

\section{References}

Adams N and Elliot C (2000) Ethnography is dogmatics: Making description central to systematic theology. Scottish Journal of Theology; 53 (3): 339-364.

Bourdieu P (2006) Outline of a Theory of Practice; trans. R Nice Cambridge University Press: New York.

Bretherton L (2012) Coming to judgment: Methodological reflections on the relationship between ecclesiology, ethnography and political theory. Modern Theology; 28 (2): 167-196.

de Certeau M (1988) The Practice of Everyday Life. Trans. Rendall S. University of California Press: Berkeley.

Flyvbjerg B (2001) Making Social Science Matter: Why Social Inquiry Fails and How it Can Succeed Again. Trans. Sampson S. Cambridge University Press: New York.

Greeve Davaney S (2000) Pragmatic Historicism: A Theology for the Twenty-First Century. SUNY Press: Albany, NY.

Healy NM (2000) Church, World and the Christian Life: Practical-Prophetic Ecclesiology. Cambridge University Press: New York.

James (2001) The New Oxford Annotated Bible: With the Apocryphal/ Deuterocanonical Books. In: Michael D Coogan (ed) New Revised Standard Version. New York: Oxford UP.

Jordan MD (2013) Writing "the Truth". Practical Matters 6 (2013), http:// practicalmattersjournal.org/issue/6/centerpieces/writing-the-truth, accessed 13 August 2015. 
Kaufman T S (2015) Normativity as Pitfall or Ally? Reflexivity as an interpretive resource in ecclesiological and ethnographic research. Ecclesial Practices; 2 (1): 91-107.

McClintock Fulkerson M (2007) Places of Redemption: Theology for a Worldly Church. Oxford University Press: New York.

Milbank J (1990) Theology and Social Theory: Beyond Secular Reason. Blackwell Publishing: Malden, MA.

Ortner S (1996) Making Gender: The Politics and Erotics of Culture. Beacon Press: Boston.

Scharen C (2005) "Judicious narratives", or ethnography as ecclesiology. Scottish Journal of Theology; 58 (2): 125-142.

Scharen C and Vigen A (eds). (2011) Ethnography as Christian Theology and Ethics. Continuum: New York.

Smith T (2004) Redeeming critique: Resignations to the cultural turn in Christian theology and ethics. Journal of the Society of Christian Ethics; 24 (2): 89-113.

Smith TA (2013) Troeltschian Questions for "Ethnography as Christian Theology and Ethics". Practical Matters 6 (2013), http://practicalmattersjournal.org/issue/ 6/centerpieces/troeltschian-questions-for-ethnography-as-christian-theologyand-ethics, accessed August 13, 2015.

Swidler S (1996) Culture in action: Symbols and strategies. American Sociological Review; 51 (2): 273-286.

Tanner K (1997) Theories of Culture: A New Agenda for Theology. Fortress Press: Minneapolis.

Wacquant L (2005) Carnal connections: On embodiment, apprenticeship, and membership. Qualitative Sociology; 28 (4): 445-474.

Ward P (2012) Perspectives on Ecclesiology and Ethnography. Eerdmans: Grand Rapids.

Ward P (2015) Blueprint ecclesiology and the lived: Normativity as perilous faithfulness. Ecclesial Practices; 2 (1): 74-90.
Webster J (2012) "In the society of god": Some principles of ecclesiology In: Ward $\mathrm{P}$ (ed). Perspectives on Ecclesiology and Ethnography". Eerdmans: Grand Rapids.

Wigg-Stevenson N (2014) Ethnographic Theology: An Inquiry Into the Production of Theological Knowledge. Palgrave Press: New York.

Williams R (1992) Saving time: Thoughts on practice, patience, and vision. New Blackfriars; 73 (861): 319-326.

\section{Data availability}

The datasets generated and analysed during the current study are not publicly available due to potential compromises in participant confidentiality. Select sections of fieldnotes are, however, reproduced elsewhere (Wigg-Stevenson, 2014).

\section{Additional Information}

Competing interests: The authors declare no competing financial interests.

Reprints and permission information is available at http://www.palgrave-journals.com/ pal/authors/rights_and_permissions.html

How to cite this article: Wigg-Stevenson N (2015) From proclamation to conversation ethnographic disruptions to theological normativity. Palgrave Communications. 1:15024 doi: $10.1057 /$ palcomms.2015.24.

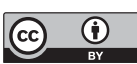

This work is licensed under a Creative Commons Attribution 3.0 International License. The images or other third party material in this article are included in the article's Creative Commons license, unless indicated otherwise in the credit line; if the material is not included under the Creative Commons license, users will need to obtain permission from the license holder to reproduce the material. To view a copy of this license, visit http://creativecommons.org/licenses/by/3.0/ 